\title{
Freshwater ecosystems: research, policy and applications
}

\author{
András Báldi ${ }^{1}$ (D) A Ágnes Vári ${ }^{1}$ (D)
}

Received: 2 September 2020 / Accepted: 31 October 2020 / Published online: 19 November 2020

(c) The Author(s) 2020

Safeguarding water is a key challenge of the twenty-first century. Freshwater is vital for our socio-economic development, food and energy provisioning, recreation, biodiversity and to maintain ecosystems and their services supporting our well-being. Water is highlighted in the sustainable development goals (SDGs) of the United Nations Development Program that give an agenda for humanity until 2030, in SDG 6 (https://www.un.org/sustainabledevelopment/water -and-sanitation/). This goal has six targets regarding drinking water, sanitation, pollution, water-use efficiency, water resource management and aquatic ecosystems, in which significant progress must be made by 2030 . These targets also indicate the large diversity of freshwater-related issues that range from human health and governance to ecosystem services.

The key role of freshwater and the strong linkages of socio-economic development to water resources are acknowledged in The Global Risk Report 2020 in which the World Economic Forum (https://www.weforum.org/ reports/the-global-risks-report-2020) assessed what risks have large impact and/or large likelihood. Water crises are in the top ten risks in terms of both impact and likelihood. However, water use is still within the planetary boundaries. The planetary boundary approach assesses the boundaries of nine environmental systems, within which humanity can survive and maintain development (https://www.stock holmresilience.org/research/planetary-boundaries.html). One of the nine systems is freshwater use, and it is within the boundaries both globally (Steffen et al. 2015) and at the European scale (EEA 2019). Importantly, this implies that we do not need to take drastic steps to reduce water usage, in contrast to the climate regulating system. It suffices to maintain the current level. This is valid at the global level, and of course, there are big differences among regions and

\footnotetext{
Ágnes Vári

vari.agnes@ecolres.hu

1 Lendület Ecosystem Services Research Group, ELKH

Centre for Ecological Research, 2-4 Alkotmány utca,

Vácrátót 2163, Hungary
}

countries. Thus, appropriate strategies are badly needed to maintain the current level of freshwater use while achieving a distribution that meets all needs. This is the point where scientific advice and evidence-based approaches must have a strong role, not only to meet the requirements above, but also to consider and integrate the predictions of the expected increase in environmental uncertainties, like flash floods, drastic droughts and heat waves (Kron et al. 2019).

Such calls for more evidence and more scientific input abound in the literature. However, these have no real effect, as they are too vague to initiate any effective steps. Thus, to be operative, we have to (1) map the knowledge gaps; (2) provide a foresight to assess future challenges; (3) prepare a research strategy to fill the gaps; (4) provide sufficient funding to carry out research to fill the knowledge gaps; and (5) monitor if the system works as expected.

An example for this approach is the Hungarian Water Research Programme, developed under the supervision of the Water Science Program of the Hungarian Academy of Sciences (Engloner et al. 2019). The Programme aims to summarize the key knowledge gaps and research challenges for Hungary, thereby providing a starting point for integrated, multi-disciplinary research. Although the focus is on Hungary, it has an international aspect as well, at the water basin level for management purposes, and at the EU level for policy coherence, especially regarding the Water Framework Directive. The Programme used a rather complex approach to define knowledge gaps as it draws upon national strategies and studies, international research strategies and treaties, expert opinions and the results of a widely distributed online questionnaire. The SDG 6 targets are applied as the main structure of the document, and each chapter lists the challenges and research tasks. This and other, similar documents-which are comprehensive enough-can be used to establish appropriate funding. However, we are at the beginning of the Programme, where publications of research results, including policy, theory and applied studies, are badly needed.

This special issue on freshwater ecosystems presents multiple aspects of water-related research with a series of 
papers from global policy and regional research to local or industrial applications and landscape-level modelling.

The first paper, 'Integrating freshwater ecosystem health in water resources management' by Bogardi et al. (2020) deals with the policy framing for ensuring the good quality of waters and gives a valuable overview of a UN-based work, the UN water quality guidelines, with an extensive compilation of international background material. It assumes that deteriorating water quality also has an effect on the quantity of water available to people, as part of the resource is no longer available for specific uses (such as drinking water). Four aspects are discussed in detail, starting with the interlinkages between human well-being and freshwater ecosystem health, followed by a suggestion to add the category of 'Stressors' to the Drivers-Pressures-State-Impacts-Responses (DPSIR) framework in order to emphasize the interface between the societal and freshwater systems. An extensive overview of different types of pressures and their action as stressors is given in the paper (e.g. flow alteration, habitat modification, overexploitation, pollution). As a response to the discussed stressors, a global response is required to halt the degradation of freshwater ecosystems. Thus, Bogardi et al. propose an iterative, adaptive frame to establish general water quality guidelines for freshwater ecosystems. This scheme has already been adopted in a somewhat modified way by the UN Environment in its Framework for Freshwater Ecosystem Management (2018) and is recommended for widespread use. For effective management, the assessment of the actual state is indispensable. Bogardi et al. analyse and compare guidelines and the applied benchmarks for monitoring freshwater ecosystem quality from eight countries/regional agencies (Australia/New Zealand, Canada, China, EU, Japan, South Africa, United Nations Economic Commission for Europe (UNECE) and the USA) and derive a set of general benchmark values for key physicochemical indicators to delimit the ranges of water quality statuses of freshwater ecosystems (from 'good' to 'unacceptable'). The authors emphasize the importance of embedding water quality guidelines for freshwater into the specific climatic, geographical and socioeconomic context in order to achieve successful implementation that is in line with the SDG targets of Goal 6.

With the second work in this issue (Felföldi 2020): 'Microbial communities of soda lakes and pans in the Carpathian Basin: a review' we step from the global perspective to an ecosystem very special within the Carpathian Basin: Felföldi reviews the available knowledge on the microbial communities of soda lakes and shallow pans. While many of these inland alkaline lakes can be found in the Eurasian Steppe, in Hungary and at the Hungarian-Austrian border we find the westernmost occurrence of these habitats (Boros and Kolpakova 2018). First, a comprehensive introduction is given regarding the main physical and chemical components of this unusual and extreme habitat type, with some illustrative pictures giving a good impression of the special features. Then the paper reviews the available literature not only on bacterial composition, but also on algae, protists, viruses and fungi, and overviews some diel changes and environmentally induced composition shifts. Even though high turbidity leads to very low euphotic depths, phytoplankton biomass was found to be quite high. Seasonal dynamics of the different algal groups are also discussed based on the reviewed literature. The review is completed by insights into the typical food-web structure of this very special habitat and with potential future applications of extracts from the very diverse bacterial community found here.

Somogyi et al. (2020) also present a review, focusing on the smallest photoautotrophic organisms in Lake Balaton, on photoautotrophic picoplankton that was discovered in the 1980s. Despite its size, picoplankton can occasionally contribute up to $70 \%$ to the phytoplankton biomass in Lake Balaton. Somogyi et al. discuss the dynamics of picoplankton in terms of seasonal or past changes in trophic levels and the environmental gradients characteristic of the lake and in relation to other phytoplankton taxa. The authors showed already in earlier works that community-level chromatic adaptation occurs along the environmental gradients in Lake Balaton. Picocyanobacteria and picoeukaryotes are distinguished, and diversity was analysed by the number of different genotypes obtained. The changes in the abundance of the different groups-also during winter time-are presented based on extensive former work of the authors.

The paper by Tóth et al. (2020) links the two previous papers in its topic and presents original research on Lake Balaton microbial communities. Using cultivation-independent methods (NGS next-generation sequencing, specific PCRs and microscopic cell counting), they discovered a much higher diversity of microbes than assumed on the basis of previous cultivation-based findings. Thus, they propose that the dominance of certain taxa needs to be re-evaluated. Their work links by the inclusion of phototrophic bacteria to previous phytoplankton-focused work by Somogyi et al. (2016 and this issue) and Kovács et al. (2012).

Carrying on with the topic of microbes, but stepping towards applied research, Felföldi et al. (2020) present an industrial application of microbiological research in waters. They review the biological treatment of coke plant effluents from a microbiological perspective. During the production process of coke, large volumes of chemically complex effluents are generated, the composition of which depends on the quality of the coal and the technology used, among other factors. These effluents can all be considered as high strength wastewater with toxic or carcinogenic compounds that need to be treated. After physicochemical treatment, biological purification takes place within activated sludge bioreactors. In this review, the authors describe key microorganisms 
involved in this purification step that can help the optimization of treatment technologies.

The special issue on water sciences is closed by a paper by Decsi et al. (2020), looking again at the big picture by analysing hydrologic functions within a watershed. The processes that take place within a whole catchment area determine the quality of the surface water run-off and finally of the stream and therefore have an influence on the biotafrom bacteria, phytoplankton, macrozoobenthos to fish and other vertebrates. Modelling the processes that depend on the ecosystems present in the watershed is therefore essential to assess the effects of potential future changes in land use. Based on the environmental factors, the suggested method also makes it possible to formulate suggestions towards conservation. For their study, Decsi et al. chose the River Zala catchment area, which is the largest tributary of the Lake Balaton and thus is of special importance to the dynamics of several of the groups reviewed in other papers of this issue (see Somogyi et al. 2020; Tóth et al. 2020).

\section{Conclusions}

Sustainable water use that satisfies societal needs while maintains the functioning of freshwater ecosystems needs considerable evidence base. Studies in this issue provide examples of the complexity of water sciences, ranging from basic science to policy and practice and from exploratory research to industrial applications. Bringing these specific aspects together within one special issue contributes to the development of a deeper and more integrated understanding of the underlying processes that is essential for managing our water resources in a sustainable way. We urge that targeted calls from research funding agencies be issued to catalyse water research in strategic directions (Engloner et al. 2019), with a focus on areas with high relevance for policy makers as well as for society.

Acknowledgements The Freshwater Ecosystems Special Issue of Biologia Futura is partly based on two symposia, the 'Aquatic Ecosystem Services-assessment, management and socio-economic challenges' (https://aquatices.ecolres.hu/) and 'The responsibility of Water Science for Sustainability', as a special session to the World Science Forum (https://worldscienceforum.org/programme/2019-11-20-the-responsibi lity-of-water-science-for-sustainability-152).

Authors' contributions Both authors contributed equally to the writing of the paper.

Funding Open access funding provided by ELKH Centre for Ecological Research. The symposia were supported by the Water Science Program and Excellence Cooperation Program (MTA KEP) of the Hungarian Academy of Sciences.

Data accessibility Not applicable.

\section{Compliance with ethical standards}

Conflict of interest The authors declare that they have no conflict of interest.

Ethical statement Not applicable.

Open Access This article is licensed under a Creative Commons Attribution 4.0 International License, which permits use, sharing, adaptation, distribution and reproduction in any medium or format, as long as you give appropriate credit to the original author(s) and the source, provide a link to the Creative Commons licence, and indicate if changes were made. The images or other third party material in this article are included in the article's Creative Commons licence, unless indicated otherwise in a credit line to the material. If material is not included in the article's Creative Commons licence and your intended use is not permitted by statutory regulation or exceeds the permitted use, you will need to obtain permission directly from the copyright holder. To view a copy of this licence, visit http://creativecommons.org/licenses/by/4.0/.

\section{References}

Bogardi JJ, Leentvaar J, Sebesvári Z (2020) Biologia futura: integrating freshwater ecosystem health in water resources management. BIOLOGIA FUTURA. https://doi.org/10.1007/s42977-020-00031 $-7$

Boros E, Kolpakova M (2018) A review of the defining chemical properties of soda lakes and pans: an assessment on a large geographic scale of Eurasian inland saline surface waters. PLoS ONE 13:e0202205

Decsi B, Vári Á, Kozma Z (2020) The effect of future land use changes on hydrologic ecosystem services: a case study from the Zala catchment, Hungary. BIOLOGIA FUTURA. https://doi. org/10.1007/s42977-020-00032-6

Engloner A, Vargha M, Báldi A, Józsa J (eds) (2019) Hungarian water research programme: challenges and research tasks. Centre for Ecological Research, Tihany

European Environment Agency (EEA) (2019) The European Environment State and Outlook 2020. Publications Office of the European Union, Luxembourg.

Felföldi T (2020) Microbial communities of soda lakes and pans in the Carpathian Basin: a review. Biologia Futura. https://doi. org/10.1007/s42977-020-00034-4

Felföldi T, Nagymáté Z, Székely A, Jurecska L, Márialigeti K (2020) Biological treatment of coke plant effluents-from a microbiological perspective. Biologia Futura. https://doi.org/10.1007/s4297 7-020-00028-2

Kovács AW, Tóth VR, Vörös L (2012) Light-dependent germination and subsequent proliferation of N2-fixing cyanobacteria in a large shallow lake. Ann Limnol Int J Limnol 48:177-185

Kron W, Löw P, Kundzewicz ZW (2019) Changes in risk of extreme weather events in Europe. Environ Sci Policy 100:74-83

Steffen W, Richardson K, Rockström J, Cornell SE, Fetzer I, Bennett EM, Biggs R, Carpenter SR, de Vries W, de Wit CA, Folke C, Gerten D, Heinke J, Mace GM, Persson LM, Ramanathan V, Reyers B, Sorlin S (2015) Planetary boundaries: guiding human development on a changing planet. Science 347:1259855

Somogyi B, Tugyi N, Vörös L (2016) A fitoplankton szezonális dinamikája a Balatonban 2016-ban. Ecol Lake Bal Bal ökol 3:16-26

Somogyi B, Felföldi T, Tóth LG, Bernát G, Vörös L (2020) Photoautotrophic picoplankton-a review on their occurrence, role and diversity in Lake Balaton. Biologia Futura. https://doi. org/10.1007/s42977-020-00030-8 
Tóth E, Toumi M, R. Farkas R Takáts K, Somodi C, Ács É (2020) Insight into the hidden bacterial diversity of Lake Balaton, Hungary. Biologia Futura. https://doi.org/10.1007/s42977-020-00040 $-6$
UN Environment (2018) A framework for freshwater ecosystem management. UN Environment, Nairobi 